\title{
Kuduz Enfeksiyonunun Moleküler Evrimi, Çeşitliliği ve Coğrafik Dağılımı
}

\author{
Yeşim Tatan', Tuba Çiğdem Oğuzoğlu² \\ ${ }^{1}$ Veteriner Kontrol Merkez Araştırma Enstitüsü Müdürlüğü, Kuduz Teşhis Laboratuvarl, Etlik, Ankara \\ ${ }^{2}$ Ankara Üniversitesi Veteriner Fakültesi, Viroloji Anabilim Dalı, Dışkapı, Ankara
}

Geliş Tarihi / Received: 20.03.2018, Kabul Tarihi / Accepted: 22.05.2018

\begin{abstract}
Özet: Kuduz, insan ve hayvan sağlığını etkileyen, önemli ve ölümcül enfeksiyöz hastalıklardan birisidir. Bu derlemede; Kuduz enfeksiyonunun moleküler orijini, tarihçesi, Kuduza sebep olan Lyssavirusların çeşitliliği, coğrafik dağılımları ile ülkemizdeki Kuduz enfeksiyonunun durumu hakkında bilgiler sunulmuştur.
\end{abstract}

Anahtar kelimeler: Kuduz, orijin, evrim, filogenetik

\section{Molecular Evolution, Diversity and Geographic Distribution of Rabies Infection}

\begin{abstract}
Rabies is one of the most important and deadly infectious diseases affecting human and animal health. In this compilation; The molecular origin of rabies infection, its history, the diversity of Lyssavirus causing the disease, its geographical distribution and the situation of the infectious disease in our country are presented.
\end{abstract}

Key words: Rabies, origin, evolution, phylogenetic

\section{Giriş}

Kuduz enfeksiyonu; tarihçesi çok eski yıllara dayanan, dünyada Antartika kıtası dışında tüm kıtalarda tespit edilmiş, her yıl enfekte karnivor kökenli 1sırma vakaları sonrası insan ölümlerinin yaşandığ 1 önemli bir viral zoonoz hastalıktır. Dünya genelinde yılda yaklaşık 60.000 kişinin Kuduz enfeksiyonundan öldüğü tahmin edilmektedir [16].

$\mathrm{Bu}$ derlemede, zoonotik öneme sahip Kuduz enfeksiyonunun etiyolojik özellikleri, moleküler orijini ve evrimi, virusların filocoğrafik dağılımı ve ülkemizdeki virus suşlarının durumu hakkında bilgiler bulunmaktadır.

\section{Virusun Özellikleri}

Kuduz enfeksiyonu, Mononegavirales sinifinın Rhabdoviridae ailesinde yer alan Lyssaviruslar tarafindan meydana getirilmektedir [10, 34]. Glikoprotein peplomerlere sahip lipid zar, helikal olarak sarılmış nükleokapsiti çevrelemektedir. Virion bu yapısıyla morfolojik olarak mermi veya koniye benzemektedir. Virus negatif polaritede, tek iplikçikli (single-stranded-ssRNA), 11-12 kb uzunluğunda ve parçalı olmayan tek molekül halinde bir genoma sahiptir. Lyssavirus virionlar1 5 majör protein içermektedir: nükleoprotein $(\mathrm{N})$, fosfoprotein
$(P)$, matriks proteini $(M)$, glikoprotein $(G)$, ve RNA bağımlı RNA polimeraz (L) proteinleridir [44].

\section{Lyssavirusların Orijini}

Lyssaviruslar'ın konakçı değişimine kanıt olarak, genotip 1'e ait eski iki virusun filojenisine bak1ld1ğında ilk bulaşmanın, rakun RABV lineajı (Doğu Amerika) ve Kuzey Amerika'da yakın ilişkili olduğu kokarca lineajının (Merkez Amerika) arasında meydana geldiği tahmin edilmekteydi. Ancak bilinmeyen bir bölgede kaynağı belli olmayan bir vektörden ikinci bir bulaşma nedeniyle carnivorların bir türünde RABV'nin var olduğu ve tüm dünyaya yayıldı̆̆ 1 tespit edilmiştir [3].

Dünyadaki Rabies olgularına bakıldığında insan vakalarının \%99'dan fazlasını köpek (Canislupus familiaris) orijinli memeli RABV (Rabies virus) meydana getirmektedir [27]. Önemli bir patojen olan Kuduz virusunun küresel filocoğrafik durumunu keşfetmek ve köpeklerde RABV evrim periyodunu anlamak için, Bayesian coalescent metoduyla $\mathrm{N}$ ve $\mathrm{G}$ genleri incelenmiş; Canid RABV lineajlarının Hindistan yarımadasından muhtemelen 1500 y1l önce ortak bir atadan köken aldığ 1 düşünülmüştür (şekil 2) [5]. RABV lineajları; Afrika 2, Afrika 3, Kutup ilişkili, Asya, Cosmopolitan ve Hindistan yarımadası dalı olarak tanımlanan farklı filogenetik 
gruplardan oluşmaktadır $[4,8,24,28]$. On beşinci yy. boyunca okyanuslar arası yolculuğun gelişmesi sonrasında "Cosmopolitan" yani çok uluslu olarak anılan köpek RABV lineajı küresel yayılım göstermiş ve tüm kıtalara Kuduz'un yayılmasında önemli bir rol oynadığı düşünülmüştür [3, 24]. Önceleri Afrika 1 olarak adlandırılan Cosmopolitan dalı Afrika'nın kuzey, güney ve merkezine dağ 11 ım göstermiştir [24]. Bu dalın Avrasya'dan büyük olas1lıkla ikinci göçleri temsil ettiği düşünülmektedir [5]. Dünya çapında yayılım göstermesinin yanı sıra yaygın olarak Afrika, Asya ve Latin Amerika gibi bölgelerde köpeklerde görülürken, aynı zamanda Kuzey Amerika'da (kokarca, gri tilki ve çakal) vahşi yaşamdaki vektörlere ait viruslarla da uyumlu olduğu belirlenmiştir [3, 35, 39].

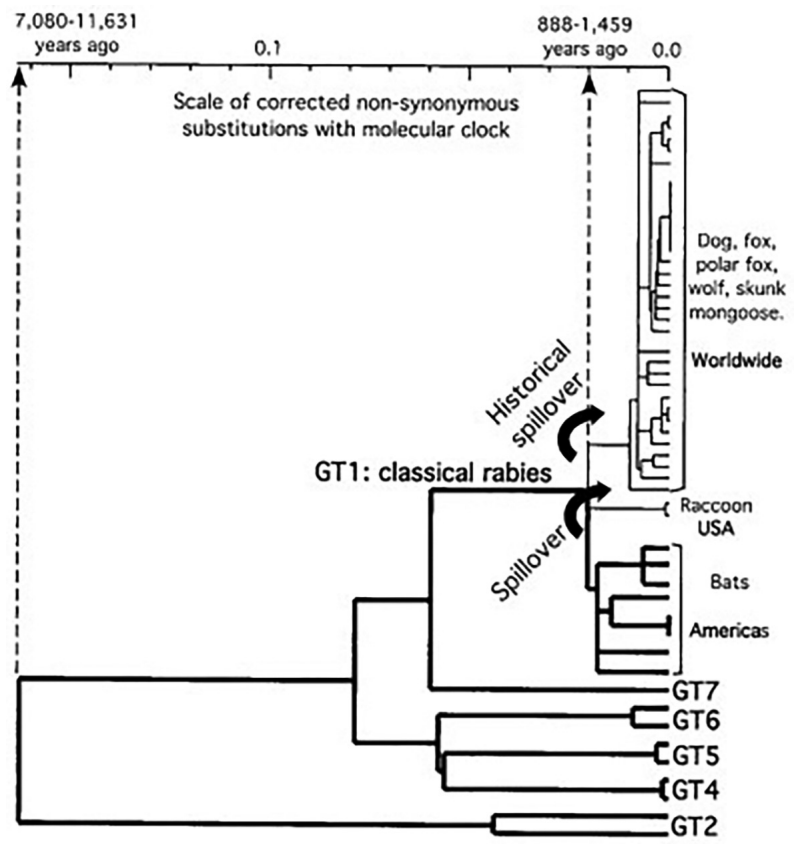

Şekil-1. Moleküler zamanlamada Lyssavirus filogenetik ağac1 [23]

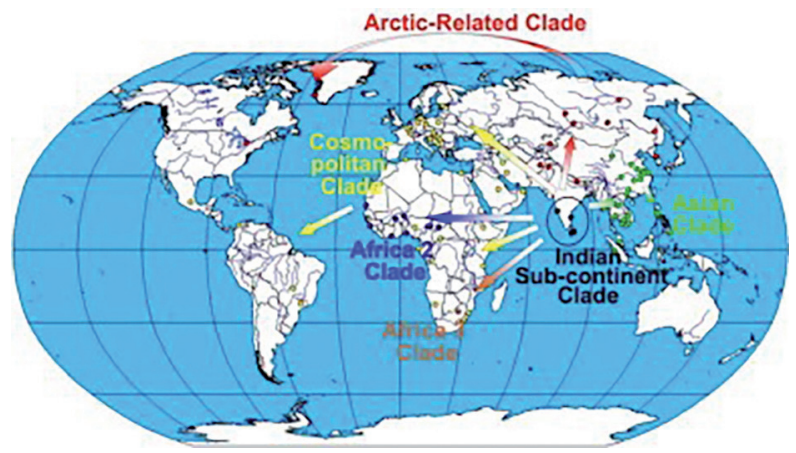

Afrika 2 ve Afrika 3 dallarının yalnızca bulundukları bölgeye spesifik olduğu görülmüştür [20]. Kutupla ilişkili dal, Grönland ve Kuzey Amerika'nın yanı sıra Asya'nın merkezinden doğusuna kadar yayılmış, tüm kuzey yarım kürede büyük bir alanı işgal eden bir dizi lineajlar olarak dolaşmaktadir [18, 24, 29, 31, 38]. Bu dal aynı zamanda İran ve Pakistan'da da dolaşmaktadır [36]. RABV'nin Hindistan yarımadası dalı yalnızca Güney Hindistan ve Sri Lanka içinde dağılmıştır [2, 37]. Yayılım için bu grubun ilk olduğu düşünüldüğünden uçamayan memelilerde RABV filojeni bazal bir pozisyon işgal ettiği için çok önemlidir [5].

Karasal memeli RABV'nin evcil köpekler aracılığıyla Hindistan yarımadasının güneyinden bir atadan köken aldığ 1 düşüncesi var olmasına rağmen, bu hipotezi desteklemek için daha geniş bir coğrafi bölgeyi temsil eden sekans örneklerinin test edilmesi gerekmektedir. Ortak ata zamanlarını tahmin etmek için kullanılan kaynaştırma temelli (Coalescent based) yöntemlerle evrimsel farklılaşmanın büyük olasılıkla son 1500 yıl içinde gerçekleştiği ön görülmektedir. 2000 y1ldan daha uzun süredir Orta Doğu'da var olan en eski canid RABV lineajlarını yeni çalışmalarda kullanabilmek; ya sonradan nesli tükenen yarasalardan bağımsız bir yayılmaya sebep olduklarından ya da farklı bir Lyssavirus genotipi olmaları sebebiyle mümkün olamamaktadır $[5,40$, 41].

Uzun dönem filocoğrafik örnekler için; lineajlar arasındaki uygun farklılıkların; bazılarının diğerlerinden daha üstün olmasına olanak vermesi sayesinde, lineajların seçici olarak ortadan kalkmasına neden olabilmektedir. Bu bazı ara lineajlar, stokastik işlemler/süreçler nedeniyle ortadan kalkabilmektedir. RABV'nin yeni konakçılara uyum sağlamasına imkan veren mutasyon faydalarının tespiti mümkün olmasına rağmen, RABV evrimi boyunca gözlenen $\mathrm{dN} / \mathrm{dS}$ değeri çok düşük olduğu için güncel metodlarla belirlenememiştir. Bu nedenle RABV'deki uzun filocoğrafik örnekler üzerinde çok daha derin etkiye sahip olan rastgele süreçler (stokastik süreç) öngörülür. Özellikle uzun periyodlar boyunca kısa dönem demografik açılımların görüldüğü bu soyların çoğunun genetik kayma ile tesadüfi şekilde kaybolması bölgesel olarak ayrı filocoğrafik dallarda ayrılmaya sebep olmuştur [5].

Şekil-2. Köpek kuduz virusunun orjin ve evrimi [1] 


\section{Lyssavirusların Evrimi}

RNA virus grubundaki Lyssaviruslar, başlıca Carnivora ve Chiroptera türlerine ait canlılar1, vektör olarak kullanırlar. Bu virusların ekolojik olarak iki farklı memeli türüne adapte olabilmesi, başarılı konakçı değişiminin olası bir sonucu olarak yorumlanmaktadır [3]. İki farklı tür arasındaki tüm protein sekanslar1; sinonim (dS) ve sinonim olmayan $(\mathrm{dN})$ yer değiştirmelerin oranı ile evrimsel süreçteki seçilimlerin etkisi değerlendirilebilmektedir $(\mathrm{dN} / \mathrm{dS}$ oranı; 1'den büyük ise pozitif seçim, 1'den küçük ise negatif seçim ve 1'e eşit ise nötr seçim) [46].

Virus-konakçı ilişkilerinde önemli bir rolü olan ve konakçı adaptasyon proteini olarak kabul edilen G proteininin sekans analizleriyle Lyssavirus'un evrimi konusunda araştırmalar yapılmış olup, ilk olarak nokta mutasyonlar ve rekombinasyon gibi evrimsel güçlerin, evrim oranı ve modelindeki önemi ortaya konulmuştur [3, 7, 33].

Filogenetik analiz sonuçları; Chiroptera'dan Carnivor'lara Lyssavirus'un başarılı konakçı değişimi olasılığını, G geni tümündeki dN/dS oranı analizleri sonucunda; Lyssavirus evriminde nokta mutasyonun ve negatif seçimin önemli rol oynadiğ 1 ve bu süreçte rekombinasyon olmadığ 1 fikrini öne çıkarmaktadır. Bu bağlamda, Chiropteran Lyssavirus'ların Carnivor RABV'den çok daha önce var olduğu ortaya konulmuştur (Şekil 1) [3, 7, 33].

dN/dS oranları kullanılarak Lyssavirus'un evrim oranı yaklaşık olarak $3,1 \times 10^{-4}$ ile $5,5 \times 10^{-4} \mathrm{dS} /$ yer/y1l olarak bildirilmektedir. Bu oran, 284 ile 504 yıl önce Cosmopolitan varyantın ayrılma tarihini ortaya koyar ki, bu zaman aralığı da son 5 yüzyıldaki yoğun insan hareketleriyle uyum göstermektedir. En eski farklılıkları değerlendirmek için kullanılan non-sinonim düzeltilmiş mesafelerle elde edilen bir filogenetik ağaç; Chiroptera'lardan Carnivor'lara Rabies Virus (RABV) konakçı değişimi zamanını 888 ile 1459 y1l öncesine dayandığını göstermektedir [3]. Bu tahminin Carnivor Kuduzu'nun günümüzden yaklaşık 4000 yıl önce tanımlandığ 1 konusu ile çelişkili olduğu görülmektedir [41]. Ancak Mezopotamya Kuduzu'ndan sorumlu Lyssavirus tipi bilinmediğinden, bu RABV lineajının; tarihsel ve/veya çevresel olaylar ya da hastalık sebepli şekillenen ölümler sonucunda nesli tükenmiş ola- bileceği kabul edilmiştir. 4000 y1l önce Carnivor Kuduzu'nun ortaya çıkışı Lyssavirus evriminin oldukça yavaş bir şekilde gerçekleştiğini yansıtmaktadır [3]. Evrimin nötral modeli, polimorfizm kaybı ya da neslinin tükenmesine neden olabilen rastgele bir genetik sürüklenme anlamına geldiği için Mezopotamya Lyssavirusu'nun neslinin tükenmesi en olası hipotezdir [26].

Lyssaviruslar; rezervuarı dışındaki konakçılara yayılabilen zoonotik enfeksiyöz ajanlar olmuşlardır. Ancak hedefindeki herhangi son konakçının ölümüne neden olduklarından dolayı, ileriye yayılım söz konusu olamamaktadır. $\mathrm{Bu}$ nedenle yeni konakçı türlerinde RABV'nin başarıyla yayılımı büyük bir adaptif meydan okumay1 göstermektedir [5, 28]. Bu durum, kısmen RABV üzerinde etkili olan güçlü seçici kısıtlamaların bir yansımasıdır. Potansiyel olarak direnci arttıran nedenler arasında, yüksek oranda zararlı mutasyonların ve dolayisiyla non-sinonim aminoasit değiş̧ikliği $(\mathrm{dN})$ oranının düşüklüğü yer almaktadır [5, 17, 25].

\section{Lyssavirus Genomik Çeșitliliği}

Kuduz virusunun yedi genotipi için (GT1-Rabies Virus, GT2-Lagos bat virus, GT3-Mokola virus, GT4-Duvenhage virus, GT5-European bat lyssavirus type 1, GT6-European bat lyssavirus type 2, GT7-Australian bat lyssavirus) full genom sekans1 kullanılarak Lyssavirus'un genomik çeşitliliği hakkında çalışmalar raporlanmıştır [9]. Uzunlukları 11918 nt.(GT7) ile 12016 nt.(GT2) arasında çeşitlilik göstermesine rağmen tüm genomların aynı yapisal organizasyona sahip olduğu ortaya konmuştur (Tablo1). Kodlama bölgelerinin tahmini boyutu genotipler arasında benzerdir ve M proteini tüm genotiplerde aynı uzunluğa sahipken P proteini çok değişkenlik göstermiştir [30, 32, 45]. Tüm genomlar çevrilmeyen bölgelerle kaplanmış (UTR- untranslated region) polisitokronik genom organizasyonuna sahiptir [32, 42]. Benzerlik oranını yansıtan genetik çeşitliliğin boyutu proteinler arasında ve içinde değişkenlik göstermekte ve sırasıyla $\mathrm{N}>\mathrm{L}>\mathrm{M}>\mathrm{G}>\mathrm{P}$ (95.2, 94.2, 92.3, 85.8, 81.5\%) amino asit benzerliğine sahip olduğu ortaya konulmuştur [9]. Bölge başına $\mathrm{d}_{\mathrm{N}} / \mathrm{d}_{\mathrm{S}}$ oranı (nonsynonymous substituons/ synonymous substituons) ölçüldügün̈de elde edilen sayısal verilere bakıldığında, Kuduz virusunun 
mutasyonlara yatkınlığının oldukça düşük olduğu bildirilmiştir $[9,15]$.

Günümüzde Lyssavirus Uluslararası Virus Taksonomisi Komitesi'ne (İnternational Committee on Taxonomy of Viruses; ICTV) göre, anti nükleokapsid monoklonal antikor panelleri ile reaksiyonda olan antijenik örnekler ve genetik mesafeler gibi sinırlandırma kriterlerine dayalı olarak, Lyssaviruslar 16 farklı virus türüne ayrılmıştır [47]. Lyssavirus türleri iki filo grubu ayrilır. Virusun antijenik ve genetik profili, filogruplar içinde de ayrilmaya imkan verir $[10,11,16]$. Filogrup 1, Rabies lyssavirus, Duvenhage lyssavirus, Avrupa bat Lyssaviruses tip 1 ve 2, Bokeloh bat Lyssavirus ve Avustralya bat Lyssavirus'u kapsamaktadır. Ayrıca, Aravan Lyssavirus, Khujand Lyssavirus ve Irkut Lyssavirus'da filogrup 1'in üyeleri arasindadır. Filogrup 2, Lagos bat Lyssavirus, Mokola lyssavirus ve Shimoni bat Lyssavirus'u içermektedir. Filogruplarda önemli bir serolojik nötralizasyon vardır, ancak fillogruplar arasında çok sınırlı kros-nötralizasyon tespit edilmiştir. Bir filogruptan inaktive edilmiş virus fareye verildiğinde oluşan antikorların aynı filogruptaki virusları nötralize ettiği ancak diğer filogruptaki viruslara etki etmediği deneysel olarak ortaya konmuştur $[10,11,16]$. Bat1 Kafkasya yarasa Lyssavirus, Ikoma Lyssavirus ve Lleida bat Lyssavirus bağımsız filogruplar oluşturabilir [47]. Ancak bu viruslara ait sinırlı izolasyon raporlanması, bu filogrupların tam olarak resmi adlandirilmasina engeldir [6, 30].

Glikoproteinin yapısında bulunan ektodomain'in antijenik bölge III bölümü viral patojeniteyi önemli ölçüde etkilemektedir. $\mathrm{Bu}$ antijenik bölgedeki iki pozitif yüklü bölge olan R333 ve K330 viral patojenitede önemli etkilere sahiptir. Glikoproteindeki bir R333 (ya da K330)'ün varlığ Kuduz virusunun Challenge Virus Standart (CVS) ya da Evelyn Rokitnicki Abelseth (ERA) suşunun virulensini belirlemektedir [3, 43]. R333'ün doğal olarak eksikliği lyssavirus'un patojenitesi üzerinde negatif etki yaratmaktadır [3]. Virulens için gerekli glykoprotein R333 bölümü filogroup 2'deki viruslarda D333 ile doğal bir şekilde yer değiştirmiştir, bu değişimin büyük olasılıkla filogrubun patojenitesinde azalmaya sebep olduğu düşünülmektedir. Afrika'daki yayılımı ve bugüne kadar az sayıda insan ve hayvan vakası raporlandığı için filogrup 2
Lyssaviruslar (genotip 2 ve 3 ) toplum ve veteriner sağlığ için daha az tehlikeli olarak görülebilmektedir $[12,13]$. Ayrıca çok az sayıda izolatlara rağmen filogrup 2 içindeki büyük genetik çeşitlilik, doğada daha büyük çeşitlilikte olabileceği konusunda fikir uyandırmalıdır. Filogrup 2 içindeki büyük hetorojenite moleküler bir fleksibilite sağlayabilir. Diğer bir yandan klasik aşı (genotip 1) ile aşılanmış birkaç hayvanın Lagos yarasa virusla mücadeleden niçin korunmadığını açıklayabilir [3, 14].

\section{Türkiye'de Kuduzun Epidemiyolojisi ve İzolatların Filogenetik Durumu}

Orta Doğu ve Doğu Avrupa arasında bir köprü gibi konumunda bulunan Ülkemiz coğrafyası dikkate alındığında, Kuduz virusunun da durumu bu bağlantıyla benzerlik göstermektedir [21]. Sekans analizleri neticesinde coğrafik orijinleri ile ilişkili olarak üç farklı dala ait Kuduz virusu'nun Türkiye'de gözlendiği sonucuna varılmıştır [21]. Batı dalı olarak adlandırılan dal Türkiye'nin batısındaki illerde yaygın, ikinci bir dal ise doğu illerinden elde edilen farklı izolatları içerisinde barındırdığından Doğu dalı olarak adlandırılmıştır [19]. Batı dalının daha önce bulunmadığı bölgelere doğru, güney ve doğu yönleri istikametinde yayılım gösterdiği belirtilmektedir [20]. Doğu dalı üzerinde yapılan genetik analizler ise; bu grubun İran, Irak ve İsrail gibi Orta Doğu ülkelerinden diğer RABV sekanslarıyla ilişkili olduğunu göstermiştir $[19,22]$. Doğu grubu içerisinde yer alan Ardahan ilinden örnekler incelendiğinde bu izolatlardan bazılarının Türkiye'nin kuzey-doğu sınır komşusu olan Gürcistan'dan elde edilenler ile çok yakın ilişkili olduğu saptanmıştır. $\mathrm{Bu}$ dal Kuzey-doğu/ Kafkas dalı olarak adlandırılmıştır. $\mathrm{Bu}$ benzerlikler; yeni virus suşlarının ülkemize girmiş olabileceği konusunda dikkat çekici veriler olarak yorumlanmaktadır $[19,22]$.

\section{Kaynaklar}

1. Assenberg R, Delmas O, Morin B, Graham C, De Lamballerie X, et al (2010) Genomics and structure/function studies of Rhabdoviridae proteins involved in replication and transcription. Antiviral Research, Elsevier Masson, 87 (2), 149-61

2. Arai YT, Takahashi H, Kameoka Y, Shiino T, Wimalaratne O \& Lodmell DL (2001). Characterization of Sri Lanka rabies virus isolates using nucleotide sequence analysis of nucleoprotein gene. Acta Virol 45, 327-333

3. Badrane H \& Tordo N (2001). Host switching in Lyssavirus history from the Chiroptera to Carnivora orders. J Virol 75, 8096-8104 
4. Bourhy H, Kissİ B, Audry L, Smreczak M, Sadkowska-Todys M, Kulonen K, Tordo N, Zmudzinski J.F.\& Holmes E.C (1999). Ecology and evolution of rabies virus in Europe. J Gen Virol 80, 2545-2557

5. Bourhy H, Reynes JM, Dunham EJ, Dacheux L, Larrous F, Huong VT, Xu G, Yan J, Miranda ME, Holmes EC (2008). The origin and phylogeography of dog rabies virus. J. Gen. Virol. 89,2673-81

6. Calisher CH, Ellison JA (2012). The other rabies viruses: The emergence and importance of lyssaviruses from bats and other vertebrates. Travel Med Infect Dis.10 (2): 69-79

7. Crawford-Miksza LK, Wadford DA, Schnurr DP (1999). Molecular epidemiology of enzootic rabies in California. J. Clin. Virol. 14: 207-219

8. David D, Hughes GJ, Yakobson BA, Davidson I, Un H, Aylan O, Kuzmin IV \& Ruppercht CE (2007). Identification of novel canine rabies virus clades in the Middle East and North Africa. J Gen Virol 88,967-980

9. Delmas O, Holmes EC, Talbi C, Larrous F, Dacheux L, Bouchier C, Bourhy H (2008). Genomic Diversity and Evolution of the Lyssaviruses. PLoS ONE 3(4):e2057

10. Dietzgen, RG, Calisher $\mathrm{CH}$, Kurath G, Kuzmin IV, Rodriguez LL, Stone DM (2012). Family rhabdoviridae. In: King, A.M.Q., ADAMS MJ, CARSTENS EB, LEFKOWITZ EJ (Eds.), Virus Taxonomy: Classification and Nomenclature of Viruses. Ninth Report of the International Committee on Taxonomy of Viruses. Elsevier, San Diego, USA, pp. 686-714

11. Evans JS, Horton DL, Easton AJ, Fooks AR, Banyard AC (2012) Rabies virus vaccines: is there a need for a pan-lyssavirus vaccine? Vaccine, 30: 7447-54

12. Familusi JB, Moore DL (1972). Isolation of a rabies related virus from the cerebrospinal fluid of a child with 'aseptic meningitis'. Afr. J. Med. Sci. 3: 93-96

13. Familusi JB, Osunkoya BO, Moore DL, Kemp GE, Fabiyi A (1972). A fatal human infection with Mokola virus. Am. J. Trop. Med. Hyg. 21: 959-963

14. Fekadu M, Shaddock JH, Sanderlin DW, Smith JS (1988). Efficacy of rabies vaccines against Duvenhage virus isolated from European house bats (Eptsicus serotinus), classic rabies and rabies-related viruses. Vaccine 6: 533-539

15. Finke S, Conzelmann KK (1999). Virus protomers determine interference by defective RNAs: selective amplification of mini-RNA vectors and rescue from cDNA by a 3' copy-back ambisense rabies virus. J Virol 73: 3818-3825

16. Fooks AR, Banyard AC, Horton DL, Johnson N, Mcelhinney L, Jackson AC (2014). Current status of rabies and prospects for elimination. Lancet. 384 (9951), 1389-1399

17. Holmes EC, Woelk CH, Kassis R \& Bourhy H (2002). Genetic constraints and adaptive evolution of rabies virus in nature. Virology 292, 247-257

18. Hyun BH, Lee KK, Kim IJ, Lee KW, Park HJ, Lee OS, An SH \& Lee JB (2005). Molecular epidemiology of rabies virus isolates from South Korea. Virus Res 114, 113-125

19. Johnson N, Black C, Smith J, Un H, Mcelhinney LM, Aylan O, Fooks AR (2003). Rabies emergence among foxes in Turkey. Journal of Wildlife Diseases, 9: 1623-1625

20. Johnson N, Un H, Vos A, Aylan O Fooks AR (2006). Wildlife rabies in western Turkey:The spread of rabies through the western provinces of Turkey. Epidemiology and Infection, 134:369-375

21. Johnson N, Un H, Fooks AR, Freuling C, Müller T, Aylan O, Vos A (2010). Rabies epidemiology and control in Turkey: Pat and Present. Epidemiology and Infection. 138, 305-312

22. Johnson N, Fooks AR, Freuling C, Müller T, Kliemt A, Un H, Aylan O, Unal N, Eskiizmirliler S, Akkoca N, Vos A (2013). The Role of Phylogeography in the Control of Wildlife Rabies in Turkey "In Introduction to Sequence and Genome Analysis III, iConcept Press Ltd..,ISBN: 978-1-922227-09-6" p:279

23. Jukes TH, Cantor CR (1969). Evolution of protein molecules, In I. H. N. Munro (ed.), Mammalian protein metabolism. Academic Press, New York, N.Y. p. 21-132.

24. Kissi B, Tordo N \& Bourhy H (1995). Genetic polymorphism in the rabies virus nucleoprotein gene. Virology 209, 526-537

25. Kissi B, Badrene H, Audry L, Lavenu A, Tordo N, Brahimi M \& Bourhy H (1999). Dynamics of rabies virus quasispecies during serial passage in heterologous hosts. J Gen Virol 80, 2041-2050.
26. Kimura M (1983). The neutral theory of molecular evolution Cambridge University Press, Cambridge, Mass

27. Knobel DL, Cleaveland S, Coleman PG, Fevre EM, Meltzer MI Miranda MEG, Shaw A, Zinsstag J, Meslin FX (2005). Re-evaluating the burden of rabies in Africa and Asia. Bull. World Health Organ, $83,360-368$

28. Kuiken T, Holmes EC, Mccauley J, Rimmelzwaan GF, Williams CS \& Grenfell BT (2006). Host species barriers to influenza virus infections. Science 312, 394-397.

29. Kuzmin IV, Botvinkin AD, Mcelhinney LM, Smith JS, Orciari LA, Hughes GJ, Fooks AR \& Rupprecht CE (2004). Molecular epidemiology of terrestrial rabies in the former Soviet Union. J Wildl Dis 40, 617-631

30. Kuzmin IV, Hughes GJ, Botvinkin AD, Orciari LA, Rupprecht CE (2005). Phylogenetic relationships of Irkut and West Caucasian bat viruses within the Lyssavirus genus and suggested quantative criteria based on the $\mathrm{N}$ gene sequence for Lyssavirus genotype definition. Virus Res 111:28-43

31. Mansfield KL, Racloz V, Mcelhinney LM, Marston DA, Johnson N, Ronsholt L, Christensen LS, Neuvonen E, Botvinkin AD. \& other authors (2006). Molecular epidemiological study of Arctic rabies virus isolates from Greenland and comparison with isolates from throughout the Arctic and Baltic regions. Virus Res 116, 1-10

32. Marston D.A, Mcelhinney L.M, Johnson N, MulleR T, Conzelmann $\mathrm{KK}$, et al (2007). Comparative analysis of the full genome sequence of European bat lyssavirus type 1 and type 2 with other lyssaviruses and evidence for a conserved transcription termination and polyadenylation motif in the G-L 3' non-translated region. J Gen Virol 88:13021314

33. Mebatsion T, Cox JH, Frost W (1992). Isolation and characterization of 115 street rabies virus izolates from Ethiopia by using monoclonal antibodies: identification of 2 isolates as Mokola and Lagos bat viruses. J.Infect. Dis. 166: 972-977

34.Müller T, Freuling, CM, Wysocki P, Roumiantzeff M, Freney J, Mettenleiter TC \& Vos A (2015). Terrestrial rabies control in the European Union: Historical achievements and challenges ahead. The Veterinary Journal, 203(1), 10-17

35. Nadin-Davis SA, Huang W, Armstrong J, Casey A, Bahloul C, Tordo $\mathrm{N}$ and Wandeler AI (2001). Antigenic and genetic divergence of rabies from bat species indigenous to Canada. Virus Res.74: 139-156

36. Nadin-Davis SA, Simani S, Armstrong J, Fayaz A \& Wandeler AI (2003). Molecular and antigenic characterization of rabies viruses from Iran identifies variants with distinct epidemiological origins. Epidemiol Infect. 131, 777-790

37. Nanayakkara S, Smith JS \& Rupprecth CE (2003). Rabies in Sri Lanka: splendid isolation. Emerg Infect Dis 9, 368-371

38. Park YJ, Shin MK \& Kwon HM (2005). Genetic characterization of rabies virus isolates in Korea. Virus Genes 30, 341-347

39. Smith JS (1996). New aspects of rabies with emphasis on epidemiology,diagnosis and prevention of the disease in the United States. Clin. Micrbiol. Rev. 9: 166-176

40. Steele JH, Fernandez PJ (1991). History of rabies and global aspects. In G.M. Baer, Ed., The Natural History of Rabies, 2nd edn. CRC Press, Boca Raton, pp.1-26

41. Thedorides J (1986). Histoire de la rage. Masson, Paris, France

42. Tordo N, Poch O, Ermine A, Keith G, Rougeon F (1986). Walking along the rabies genome: is the large G-L intergenic region a remnant gene? Proc Natl Acad Sci U S A 83: 3914-3918

43. Tuffereau C, Leblois H, Benejean J, Coulon P, Lafay F, Flamand A (1989). Arjinine or lysine in position 333 of ERA and CVS glycoprotein is necessary for rabies virulence in adult mice. Virology 172:206212

44. White DO \& Fenner F (1994). Medical virology. Gulf Professional Publishing. 4th. Ed. Chapter 29, Rhabdoviridae, 475-488

45. Wu X, Franka R, Velasco-Villa A, Rupprecht CE (2007). Are all lyssavirus genes equal for phylogenetic analyses? Virus Res 129: 91-103

46. Yang Z, Nielsen R (2000). Estimating Synonymous and Nonsynonymous Substitution Rates Under Realistic Evolutionary Models. Molecular Biology and Evolution, 17 (1), 32-43

47. http://www.who-rabies-bulletin.org/site-page/classification 30/10/2017 